\title{
APPOINTMENT OF REGISTRAR.
}

Dr. Alfred Miller, Superintendent of the Warwick County Asylum, was, at the Council Meeting on February 14th, 1902, appointed to fill the post of Registrar until the next Annual Meeting.

\section{NOTICES BY THE REGISTRAR.}

\section{Next Examination for Nursing Certipicate.}

The next examination will be held on Monday, May 5 th, 1902.

Note.-As the names of some of the persons to whom the Nursing Certificate has been granted have been removed from the register, employers are requested to refer to the Registrar in order to ascertain if a particular name is still on the roll of the Association. In all inquiries the number of the certificate should be given.

\section{Examination for the Professional Certificate.}

The next examination for the Certificate in Psychological Medicine will be held in July, 1902.

The examination for the Gaskell Prize will take place at Bethlem Hospital, London, in the same month, and the examiners are authorised to award a second prize in this competition should one of the candidates attain such a standard as would justify them in doing so. Due notice of the exact dates will appear in the medical papers.

For further particulars respecting the various examinations of the Association apply to the Acting Registrar, Dr. Alfred Miller, Warwick County Asylum, Hatton, Warwick.

\section{Prize Dissertation.}

Although the subjects for the essay in competition for the Bronze Medal and Prize of the Association are not limited to the following, in accordance with custom the President suggests-

1. On the advantage of providing hospitals in asylums for acute mental cases.

2. Causation of colitis in asylums, and how it can be prevented.

3. State care of the insane.

The Manuscript Prize Dissertation and every accompanying drawing and preparation will become the property of the Association, to be published in the Journal at the discretion of the editors. The dissertation, for the Association Medal and Prize of Ten Guineas, must be delivered to the Acting Registrar, Dr. Alfred Miller, Warwick County Asylum, Hatton, Warwick, before May 30th, 1902, from whom all particulars may be obtained.

By the rules of the Association the Medal and Prize are awarded to the author (if the dissertation be of sufficient merit) being an assistant medical officer of any lunatic asylum (public or private) or of any lunatic hospital in the United Kingdom. The author need not necessarily be a member of the Medico-Psychological Association.

\section{THE CRAIG COLONY PRIZE FOR ORIGINAL RESEARCH IN EPILEPSY.}

Dr. Frederick Peterson, of New York City, offers a prize of $\$ 200.00$ for the best original unpublished contribution to the pathology and treatment of epilepsy. Originality is the main condition. All manuscript should be submitted in English. The prize is open to universal competition. Each essay must be accompanied by a sealed envelope, containing the name and address of the author and bearing upon the outside a motto or device, which is to be inscribed also upon the essay. All papers received will be submitted to a committee, consisting of three 
members of the New York Neurological Socidty, and the award will be made upon its recommendation at the annual meeting of the Board of Managers of the Craig Colony, October 14th, 1902.

Manuscripts should be sent to Dr. Frederick Peterson, 4, West Fiftieth Street, New York City, on or before September 30th, 1902. The successful essay becomes the property of the Craig Colony, and will be published in its medical reports.

\section{NOTICES OF MBETHNGS.}

\section{Medico-Psychological Association.}

General Meeting.-The next General Meeting will be held in London on Wednesday, May 2 ist next.

A discussion on "The Treatment of Sleeplessness in Mental Disease" will be opened by Dr. Rayner. All asylum medical officers are invited to join in the discussion and record their observations. The following, among others, have promised to take part :-Drs. Blandford, Harry Campbell, Hyslop, Mercier, Savage, Claye Shaw, and Outterson Wood.

Annual Meeting. - The Annual Meeting will be held at Liverpool, under the presidency of Dr. Wiglesworth, on July 24th and 25th next. Any member desiring either to contribute papers, to record cases, or to give a demonstration should, at the earliest date possible, communicate with the Hon. Secretary at II, Chandos Street, Cavendish Square, London, W.

Northern and Midland Division.-The Spring Meeting will be held on Wednesday, April 16th, at Shaftesbury House, Formby, Liverpool. Papers will be read on "Calcification of the Pericardium," by Dr. F. V. Simpson, and on "Pupillary Symptoms in the Insane and their Import," by Dr. T. P. Cowen.

South-Western Division.-The Spring Meeting will be held at the County Asylum, Cotford, near Taunton, on Tuesday, April 22nd. Business meeting at 2.45 p.m. Papers will be read on "The Evolution of Delusions in some Cases of Melancholia," by Dr. Weatherly, and on "The Care of Idiots and Imbeciles," by Dr. Sproat.

South-Eastern Division. - The Spring Meeting will be held at the Surrey County Asylum, Brookwood, on Wednesday, April 3oth. Papers will be read on "The Treatment of Colitis," by Dr. Niel Harrismith MacMillan, and on "Some Cases of Morphinomania," by Dr. Robert Jones.

Irish Division.-The next meeting will be held at the Royal College of Physicians, Dublin, early in May, 1902.

\section{AMERICAN MEDICO-PSYCHOLOGICAL ASSOCIATION.}

Annual Megting at the Windsor Hotel, Montreal, JUNE 17TH, 18Th, 19TH, 20TH, 1902.

President, R. J. Preston, M.D., Marion, Va.; Vice-President, G. Alder Blumer, M.D., Providence, R.I.; Secretary and Treasurer, C. B. Burr, M.D., Flint, Mich.; Auditors, Wm. M. Edwards, M.D., and Nelson H. Beemer, M.D.

The fifty-eighth annual meeting of the American Medico-Psychological Association will be held in Montreal the third Tuesday, Wednesday, Thursday, and Friday in June (17th, 18th, 19th, and 20th), 1902. The meeting follows that of the American Medical Association at Saratoga, which occurs in the second week in June. The matter of transportation has been placed in the hands of the Committee of the latter Association, and it is hoped to obtain special railroad rates for both meetings.

The annual address will be delivered by Dr. Wyatt Johnston, Lecturer on Medical Jurisprudence, McGill University Law Faculty. Subject: "The Medico. Legal Appreciation of Trauma in its Relation to Abnormal Mental Conditions."

XI.VIII. 